\title{
Incidence of local complications and risk factors associated with peripheral intravenous catheter in neonates*
}

\author{
Incidência de complicações locais e fatores de risco associados \\ ao cateter intravenoso periférico em neonatos \\ Incidencia de complicaciones locales y factores de riesgo asociados \\ con el catéter intravenoso periférico en neonatos
}

Mitzy Tannia Reichembach Danski ${ }^{1}$, Priscila Mingorance ${ }^{1}$, Derdried Athanasio Johann ${ }^{1}$, Stela Adami Vayego ${ }^{1}$, Jolline Lind ${ }^{1}$

How to cite this article:

Danski MTR, Mingorance P, Johann DA, Vayego SA, Lind J. Incidence of local complications and risk factors associated with peripheral intravenous catheter in neonates. Rev Esc Enferm USP. 2016;50(1):22-8. DOI: http://dx.doi.org/10.1590/S0080-623420160000100003

\footnotetext{
* Extracted from the dissertation "Complicações relacionadas ao uso do cateter intravenoso periférico em neonatos", Universidade Federal do Paraná, 2013.

${ }^{1}$ Universidade Federal do Paraná, Setor de Ciências da Saúde, Curitiba, Paraná, Brazil.
}

\begin{abstract}
Objective: To evaluate the incidence of complications related to the use of peripheral intravenous catheter in neonates and identify the associated risk factors. Method: Prospective cohort study conducted in a Neonatal Intensive Care Unit. Participants were the hospitalized neonates undergoing peripheral intravenous puncture in the period from February to June 2013. Results: The incidence of complications was 63.15\%, being infiltration/extravasation (69.89\%), phlebitis (17.84\%) and obstruction (12.27\%). The risk factors were the presence of infection $(p=0.0192)$ and weight at the puncture day $(p$ $=0.0093)$, type of intermittent infusion associated with continuous infusion $(p<0.0001)$, endotracheal intubation $(\mathrm{p}=0.0008)$, infusion of basic plan $(\mathrm{p}=0.0027)$, total parenteral nutrition $(P=0.0002)$, blood transfusion associated with other infusions $(p=0.0003)$ and other drugs $(p=0.0004)$. Higher risk of developing complications in the first 48 hours after puncture. Conclusion: A high rate of complications related to the use of peripheral intravenous catheter, and risk factors associated with infection, weight, drugs and infused solutions, and type of infusion.
\end{abstract}

\section{DESCRIPTORS}

Infant, Newborn; Catheterization, Peripheral; Risk Factors; Neonatal Nursing.
Corresponding author: Derdried Athanasio Johann

Av. Lothário Meissner, 632 - Bloco Didático II $3^{\circ}$ andar, Sala do TIS - Bairro Jardim Botânico CEP 80210-170 - Curitiba, PR, Brazil derdried.johann@ifpr.edu.br
Received: 05/27/2015

Approved: 10/06/2015 


\section{INTRODUCTION}

The intravenous therapy uses intravenous devices as fundamental instruments, which are the commonly used technologies in the care of high-risk newborns ${ }^{(1)}$. Although its use can lead to health problems in this population, nursing has the role of preventing complications that may result from the own patients, the device used and/or the care provided.

The extensive use of peripheral intravenous catheters (PIVC) is observed in the treatment of patients in healthcare facilities ${ }^{(2-3)}$. Local complications in peripheral intravenous therapy occurring around the puncture site are subject to observation and can be classified as infiltration, extravasation, thrombosis, phlebitis, thrombophlebitis, hematoma and local infection. It is necessary to observe the peripheral venous puncture constantly for the early identification of complications in order to minimize their severity ${ }^{(4)}$.

The low durability of peripheral intravenous catheters is an important factor, and the frequent occurrence of complications stands out. A study conducted in the neonatal unit of the University Hospital Rio Hortega in Valladolid surveyed 143 catheters inserted in 68 neonates, and showed that the most frequent complications were extravasation (48.3\%) and phlebitis $(3.5 \%)^{(5)}$.

Maintaining peripheral venous puncture in high-risk newborns is a challenge for nursing professionals given the particularities of this clientele, such as capillary fragility, and physiological and clinical vulnerability. Thus, this study aimed to evaluate the incidence of local complications related to the use of peripheral intravenous catheter in neonates and identify the risk factors associated with the development of complications related to its use.

\section{METHOD}

This is a prospective, observational, cohort study. It was conducted at the Neonatal Intensive Care Unit (NICU) of a teaching hospital in the city of Curitiba, state of Paraná (Brazil). The study participants were all newborns admitted to the NICU and submitted to PIVC puncture in the data collection period (February 1 to June 30,2013). Data collection occurred daily, in the afternoon, without interruption, in the presence of two researchers, by reading the information contained in the medical records of neonates, direct observation of the device, with use of an instrument with closed questions addressing sociodemographic and clinical data, as well as data related to the insertion, manipulation and removal of the catheter. To avoid bias in data collection, the research team went through daily training during three months, guided by the principal investigator. The observed concepts were standardized based on the scientific literature, in meetings with all the research team.

The newborns were followed from the time of admission until the outcome of their admission to the NICU (discharge, transfer or death), except for those who remained hospitalized and underwent a catheter puncture on June 30,2013, when the device was removed. The puncture and manipulation of device were carried out by the unit nursing team, trained for these procedures.
The data collection instrument consisted of sociodemographic and clinical variables, and catheter data. Continuous maintenance was considered when the infusion time of the solution was more than 2 hours, and intermittent maintenance when the time of drug administration was less than 2 hours.

Data were entered into Microsoft Excel ${ }^{\circledR}$ spreadsheets and analyzed using the Bioestat ${ }^{\oplus}$ program. The variable of research response (or outcome) was the occurrence of complications. In the analysis of factors that could interfere with the response variable, the chi-square test and G Williams test were used for categorical explanatory variables, while the $U$ test and the Mann-Whitney test were used for quantitative explanatory variables. In all tests was adopted $5 \%$ significance level. The calculation of relative risk was applied to measure the degree of association. The category considered as reference is shown in the table of results with value 1.0 in the column for relative risk values (RR).

The ethical guidelines were followed according to Resolution number $466 / 12$ of the National Health Council (NHC), and as unified by the Research Ethics Committee and $\mathrm{Co}$-participating Institution number 165.675.

\section{RESULTS}

The sample included 145 neonates using 677 peripheral intravenous catheters, corresponding to an average of 4.67 catheters per newborn. Of the 677 catheters used, in 251 $(37.08 \%)$ the reason for removal was not registered in the medical record. Of the 426 catheters with information on the reason for removal, 157 (36.85\%) had no complications, being 107 (68.15\%) elective reasons for removal (for completion of therapy, discharge and death) and 50 (31.85\%) accidental removals (Figure 1).

The incidence of complications among catheters was $63.15 \%(n=269)$, of which $48(17.84 \%)$ were phlebitis, 188 (69.89\%) infiltration/extravasation and 33 (12.27\%) obstruction (Figure 1). The complications of infiltration and extravasation were grouped because the nursing staff did not differentiate these classifications. Note that in $21.56 \%(n=58)$ of the first catheter used by neonates there were complications. Obstruction and infiltration/extravasation were recurrent in the first catheter, but phlebitis had the highest occurrence rates in the fourth catheter inserted in the same neonate.

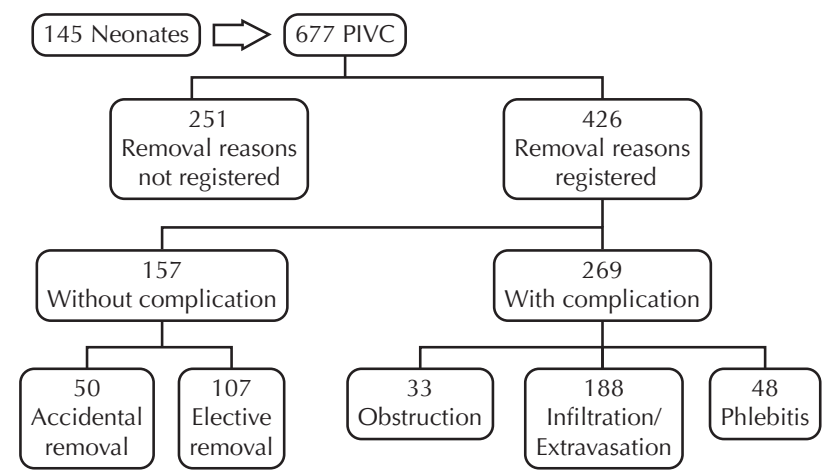

Figure 1 - Catheter distribution according to reason for removal - Curitiba, PR, Brazil, 2013. 
The complications related to PIVC use are independent of the puncture site. The sites with more complications were the upper limbs, with predominance of the left $(n=85$; $19.95 \%)$ and right $(\mathrm{n}=77 ; 18.08 \%)$ upper limbs, followed by the right lower limb $(n=44 ; 10.33 \%)$ and head $(n=36$, 8.45\%). The development of complications in all anatomical regions is noteworthy. The catheter punctures in the dorsal arch of the hand were the most common $(n=80 ; 18.78 \%)$, followed by punctures in the dorsal arch of the feet $(n=45$; $10.56 \%)$. It was also observed that all catheter punctures in the axilla $(\mathrm{n}=8,1.88 \%)$ and external jugular vein $(\mathrm{n}=2$; $0.47 \%)$ developed complications.

The analysis of risk factors associated with complications in PIVC use occurred by grouping and comparing the catheters with the presence or absence of complications.

Newborns with infection on the puncture day are 1.26 times more likely to develop complications $(p=0.0192$; $\mathrm{RR}=1.26$ ); it was observed that the lower the weight of the newborn on the puncture day, the greater the risk of complications $(\mathrm{p}=0.0093, \mathrm{RR}=1.29$ and $\mathrm{RR}=1.25)$. The type of intermittent infusion decreases the risk of developing a complication, and the intermittent infusion associated with continuous infusion increases the risk of developing PIVC complications ( $\mathrm{p}<0.0001: \mathrm{RR}=\mathrm{RR}=0.70$ and 1.23, respectively). The neonates undergoing endotracheal intubation (EI) associated with PIVC use are 1.31 times more likely to develop a complication in this catheter $(\mathrm{p}=0.0008$; $\mathrm{RR}=1.31)$ (Table 1).

It was demonstrated that the use of the catheter in the administration of basic plan increases by 1.24 times the risk of developing complications $(\mathrm{p}=0.0027, \mathrm{HR}=1.24)$. The total parenteral nutrition administration (TPN) increases the risk by 1.33 times, and the exclusive TPN administration via peripheral catheter increases by 1.62 times the risk of developing complications $(\mathrm{p}=0.0002, \mathrm{RR}=1.33$ and $R R=1.62$, respectively). The use of catheter for blood transfusion associated with other infusions increases the risk by 1.23 times, however, the exclusive use of catheter for blood transfusion reduces the risk by 0.37 times $(p=0.003 ; R R=$ 1.23 and $R R=0.37$, respectively). The administration of other drugs increases the risk by 1.31 times $(\mathrm{p}=0.0004 ; \mathrm{RR}=$ 1.31). There is a greater risk of developing a complication in the first 48 hours after the puncture $(p=0.0121)($ Table 1$)$.

Table 1 - Analysis of variables related to the catheter and its use associated with the occurrence of complications - Curitiba, PR, Brazil, 2013.

\begin{tabular}{|c|c|c|c|c|c|c|c|}
\hline \multirow{3}{*}{ Variable } & \multicolumn{4}{|c|}{ Complication } & \multirow{3}{*}{ P-value } & \multirow{3}{*}{$\mathbf{R R}$} & \multirow{3}{*}{$\mathrm{CI}[95 \%]$} \\
\hline & \multicolumn{2}{|c|}{ Yes } & \multicolumn{2}{|c|}{ No } & & & \\
\hline & $n=269$ & $\%$ & $\mathrm{n}=157$ & $\%$ & & & \\
\hline Complication & 269 & 63.15 & 157 & 36.85 & - & - & - \\
\hline $\begin{array}{l}\text { Preexisting infection } \\
\text { No } \\
\text { Yes }\end{array}$ & $\begin{array}{c}223 \\
46\end{array}$ & $\begin{array}{l}82.90 \\
17.10\end{array}$ & $\begin{array}{c}143 \\
14\end{array}$ & $\begin{array}{l}91.08 \\
8.92\end{array}$ & $0.0192^{1}$ & $\begin{array}{c}1 \\
1.26\end{array}$ & {$[1.07 ; 1.48]$} \\
\hline $\begin{array}{l}\text { Procedure performed by } \\
\text { Nurse } \\
\text { Assistant/Technician } \\
\text { Others }\end{array}$ & $\begin{array}{c}38 \\
230 \\
1\end{array}$ & $\begin{array}{c}14.13 \\
85.50 \\
0.37\end{array}$ & $\begin{array}{c}27 \\
130 \\
0\end{array}$ & $\begin{array}{c}17.20 \\
82.80 \\
0.00\end{array}$ & $0.5333^{2}$ & $\begin{array}{c}1 \\
1.09\end{array}$ & {$[0.88 ; 1.36]$} \\
\hline $\begin{array}{l}\text { Period of puncture } \\
\text { Day } \\
\text { Evening }\end{array}$ & $\begin{array}{l}164 \\
105\end{array}$ & $\begin{array}{l}60.96 \\
39.03\end{array}$ & $\begin{array}{l}81 \\
76\end{array}$ & $\begin{array}{l}51.59 \\
48.41\end{array}$ & $0.0590^{1}$ & $\begin{array}{c}1 \\
1.15\end{array}$ & {$[0.99 ; 1.34]$} \\
\hline $\begin{array}{l}\text { Weight on the puncture day } \\
<1500 \\
1500<\mathrm{p}<2500 \\
>2500\end{array}$ & $\begin{array}{l}101 \\
81 \\
87\end{array}$ & $\begin{array}{l}37.55 \\
30.11 \\
32.34\end{array}$ & $\begin{array}{l}44 \\
39 \\
74\end{array}$ & $\begin{array}{l}28.03 \\
24.84 \\
47.13\end{array}$ & $0.0093^{1}$ & $\begin{array}{l}1.29 \\
1.25 \\
1\end{array}$ & $\begin{array}{l}{[1.08 ; 1.54]} \\
{[1.03 ; 1.51]}\end{array}$ \\
\hline $\begin{array}{l}\text { Punctured limb } \\
\text { UL } \\
\text { LL } \\
\text { Others }\end{array}$ & $\begin{array}{c}162 \\
69 \\
38\end{array}$ & $\begin{array}{l}60.22 \\
25.65 \\
14.13\end{array}$ & $\begin{array}{l}89 \\
38 \\
30\end{array}$ & $\begin{array}{l}56.69 \\
24.20 \\
19.11\end{array}$ & $0.3996^{1}$ & $\begin{array}{c}1 \\
1.00 \\
0.87\end{array}$ & $\begin{array}{l}{[0.84 ; 1.18]} \\
{[0.69 ; 1.09]}\end{array}$ \\
\hline $\begin{array}{l}\text { Type of infusion } \\
\text { Continuous } \\
\text { Intermittent } \\
\text { Both }\end{array}$ & $\begin{array}{l}108 \\
27 \\
134\end{array}$ & $\begin{array}{l}40.15 \\
10.04 \\
49.81\end{array}$ & $\begin{array}{l}72 \\
37 \\
48\end{array}$ & $\begin{array}{l}45.86 \\
23.57 \\
3057\end{array}$ & $\begin{array}{c}< \\
0.00011\end{array}$ & $\begin{array}{c}1 \\
0.70 \\
1.23\end{array}$ & $\begin{array}{l}{[0.52 ; 0.96]} \\
{[1.06 ; 1.42]}\end{array}$ \\
\hline $\begin{array}{l}\text { Associated use of CVC } \\
\text { No } \\
\text { Yes }\end{array}$ & $\begin{array}{c}218 \\
51\end{array}$ & $\begin{array}{l}81.04 \\
18.96\end{array}$ & $\begin{array}{c}132 \\
25\end{array}$ & $\begin{array}{l}84.08 \\
15.92\end{array}$ & $0.4298^{1}$ & $\begin{array}{c}1 \\
1.08\end{array}$ & [0.90;1.29] \\
\hline $\begin{array}{l}\text { Associated use of BCD } \\
\text { No } \\
\text { Yes }\end{array}$ & $\begin{array}{c}259 \\
10\end{array}$ & $\begin{array}{l}96.28 \\
3.72\end{array}$ & $\begin{array}{c}155 \\
2\end{array}$ & $\begin{array}{c}98.73 \\
1.27\end{array}$ & $0.1271^{1}$ & $\begin{array}{c}1 \\
1.33\end{array}$ & {$[1.02 ; 1.73]$} \\
\hline $\begin{array}{l}\text { Associated EI } \\
\text { No } \\
\text { Yes }\end{array}$ & $\begin{array}{c}187 \\
82\end{array}$ & $\begin{array}{l}69.52 \\
30.48\end{array}$ & $\begin{array}{c}132 \\
25\end{array}$ & $\begin{array}{l}84.08 \\
15.92\end{array}$ & 0.00081 & $\begin{array}{c}1 \\
1.31\end{array}$ & {$[1.14 ; 1.50]$} \\
\hline $\begin{array}{l}\text { Associated surgery } \\
\text { No } \\
\text { Yes }\end{array}$ & $\begin{array}{c}260 \\
9\end{array}$ & $\begin{array}{l}96.65 \\
3.35\end{array}$ & $\begin{array}{c}155 \\
2\end{array}$ & $\begin{array}{c}98.73 \\
1.27\end{array}$ & $0.1808^{1}$ & $\begin{array}{c}1 \\
1.31\end{array}$ & {$[0.98 ; 1.74]$} \\
\hline
\end{tabular}

continued... 


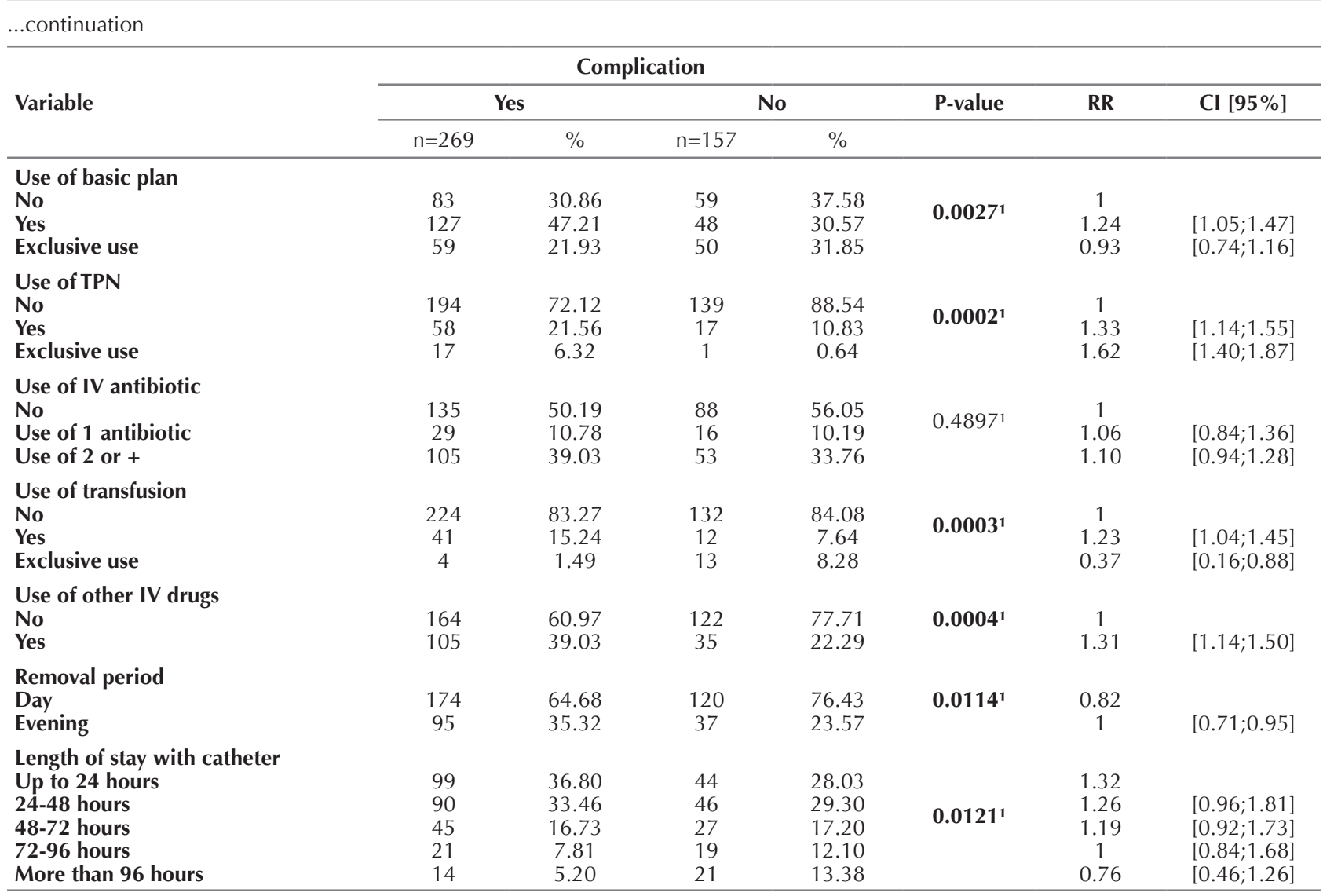

Legend: ${ }^{1}$ Chi-square test; ${ }^{2} \mathrm{G}$ William test; RR - Relative risk; CI [95\%] - 95\% confidence interval. Acronyms: upper limb (UL); lower limb (LL); central venous catheter (CVC); bladder catheterization delay (BCD); endotracheal intubation (EI); total parenteral nutrition (TPN).

\section{DISCUSSION}

\section{INCIDENCE OF COMPLICATIONS}

The incidence of complications was estimated at $63.15 \%$ of cases. Despite the high value, the percentage found is within the limits described in studies with a similar population, which demonstrated the variability of 55.3 to $83 \%$ of developing complications $s^{(3,5-7)}$. Regarding the complications listed in this study, there was predominance of infiltration/ extravasation (69.89\%), followed by phlebitis (17.84\%) and obstruction (12.27\%). The literature is in line with these data when describing infiltration $(20-56 \%)^{(3,6-8)}$ and extravasation $(24$ to $48,3 \%)$ as the most frequent complications ${ }^{(5,7)}$.

The infiltration/extravasation rate (69.89\%) observed in this study was high compared to the literature. The physiology of newborns is characterized as a predisposing factor for developing infiltration and extravasation due to capillary fragility. Some authors highlight that newborns have a particular risk of developing infiltration/extravasation because their subcutaneous tissue is flexible and stretches easily in the presence of liquid, and they also have impaired venous integrity, which facilitates capillary leak ${ }^{(9)}$. These factors can be directly related to the profile of the population hospitalized in the NICU, since these clients have clinical instability and require intensive care because of prematurity, low birth weight, and inadequate gestational age and Apgar ${ }^{(10)}$.

Thus, the best way to prevent infiltration and extravasation is the continuous observation of the catheter puncture site and immediate intervention upon the occurrence of these complications. A study carried out in Australia and New Zealand shows that two-thirds of the NICU use protocols for preventing these complications by adopting measures such as the nursing continuous observation of the device insertion site, keeping the insertion ostium of the catheter visible, and saline infusion before administration of other substances ${ }^{(11)}$.

In the case of fluids infused in the catheter, the literature highlights four characteristics that facilitate the risk of extravasation, namely: extreme $\mathrm{pH}$ (less than 5 or greater than 9); osmolarity (number of particles per kilogram of solvent); vasoactivity (ability to cause constriction of the vessel); and cytotoxicity (ability to cause cell damage or death). Regardless of the infused solution, its characteristics change according to the concentration of the drug and diluent used in the preparation of the intravenous mixture, causing cell damage or death of the vessel tissue. The infusion of other solutions, even the isotonic, can result in serious harm to patients, including compartment syndrome, ischemia and permanent loss of tissue function ${ }^{(12)}$.

In cases of infiltration/extravasation, the immediate removal of the catheter is the most prevalent conduct, followed by limb elevation, perforation of extravasation site and use of hot or cold compress ${ }^{(11)}$. After the occurrence of a complication, the size of the infiltration in relation to the affected area must be evaluated to use specific interventions $s^{(2)}$, a very important practice for preventing damage to newborns. 
When considering phlebitis percentages (17.84\%), this study found a higher value than other studies, which vary between 3.5 and $14 \% \%^{(3,5,7)}$. According to international clinical practice guidelines, the acceptable phlebitis percentages are less than $5 \%{ }^{(13-14)}$. Phlebitis prevention practices involve performing hand hygiene procedures, either by handwashing with soap and water using the conventional technique, or by rubbing hands with $70 \%$ alcohol and removing the catheter if the patient develops signs of inflammation ${ }^{(4)}$.

Considering the complication rates due to catheter obstruction, the present study has found indices (12.27\%) in the interval of values reported by other studies, in which the obstruction ranged from 1.4 to $39 \%(3,5,7)$.

Aiming at the minimization of complications related to PIVC use, the nurse team must pay attention for the early recognition, using the routine evaluation by continuous observation and palpation of the puncture site for the presence of signs of inflammation and exudate ${ }^{(4,13,15)}$. These actions can minimize the pain and suffering of newborns in complications resultant from peripheral intravenous therapy.

\section{RISK FACTORS RELATED TO THE CATHETER}

The presence of bloodstream infection on the puncture day (related to the catheter or not) showed statistical significance for the development of complications $(\mathrm{p}=0.0192)$. In other words, when the newborns had bloodstream infection, they were likely to develop complications in the peripheral catheter. A literature systematic review conducted between 2000 and 2011 in a population of newborns showed lower infection rates associated with the PIVC ${ }^{(16)}$. However, the infection rates can be triggered by several health care-related factors, considered preventable through the development of health educational practices with nursing professionals ${ }^{(17)}$.

There was a higher risk of developing complications during catheter use $(p=0.0093)$ when related to the lower weight of neonates on the puncture day, because the inadequate development of their physiological aspects characterizes a risk factor for errors, including adverse events in newborns resulting in catheter loss ${ }^{(17)}$.

Another variable related to PIVC complications was the concomitant use of EI ( $p=0.0008)$. This is a gateway to microorganisms that can trigger systemic complications for newborns, causing instability in the clinical picture and promoting the development of catheter complications.

In relation to the type of infusion for the prescribed intravenous treatment, intermittent infusion solution is the most favorable for this population because it minimizes the risk of developing complications with the PIVC. In contrast, the intermittent infusion associated with continuous infusion increases the risk of developing a complication in the catheter $(p<0.0001)$. By analyzing this information, it was found that the most common complication (infiltration/extravasation) found in the present study is more likely to occur during continuous infusion of solutions.

A study developed with newborns has compared groups that used intermittent and continuous infusion. It found that the intermittent infusion showed a more significant infection occurrence (71.4\%) than the continuous infusion
$(40 \%)^{(3)}$. However, regardless of the type of infusion used, it is recommended to use an aseptic technique to perform the care of the catheter ${ }^{(4)}$.

The infused solutions more associated with the occurrence of complications are the administration of basic plan, TPN, blood transfusion, associated with other infusions and the infusion of other medicaments. The administration of basic plan $(p=0.0027)$ is characterized by a continuous infusion, which may be related to the infiltration/extravasation complication.

In the administration of TPN ( $p=0.0002)$, in addition to the continuous infusion, there is the risk factor of the solution concentration, which can be harmful to the fragile venous network of newborns. A study conducted in Chile on the TPN theme found that children with bloodstream infection increased the average length of TPN use ( $\mathrm{p}<0.0001)$, and the hospitalization prior to the beginning of the TPN $(\mathrm{p}<0.0001)^{(18)}$. Another study adds that TPN and antibiotics are among the drugs that characterize risk for developing extravasation injuries in children when administered via PIVC $^{(12)}$.

In this study, the catheter puncture exclusively for blood transfusion appeared as favorable. However, the use of catheter for blood transfusion associated with other infusions is a risk factor for developing complications $(p=0.003)$.

There were less catheter removals with complication in the daytime period $(p=0.0114)$. This study indicated a greater risk of developing complications in the first 48 hours after catheter puncture $(p=0.0121)$. Such complications occur especially in the first 48 hours of life of the newborn, which also corresponds to the puncture period of the first catheter. After birth, the newborns are routed directly to the NICU, where there is a routine peripheral catheterization at the time of hospitalization. After undergoing intravenous therapy, the clinically, physiologically and anatomically fragile neonates receive treatment in order to stabilize and balance their general conditions, reducing complications after their first 48 hours of life. Moreover, with improvement of the clinical picture of newborns, the catheters remained for a longer time and there was a reduction in the development of complications.

The implications for nursing practice involve the knowledge of complications and their risk factors in order to avoid them and guide the conduct related to PIVC surveillance, which should be intensified especially in the first 48 hours of life, when the neonate has hemodynamic instability and there is greater development of complications. The limiting factors of the study relate to the incomplete medical records of the reasons for catheter removal, and the absence of information to determine the level of complications. It is suggested that similar studies are developed in order to contemplate degrees of phlebitis, infiltration and extravasation, and the proper distinction of the latter two.

\section{CONCLUSION}

The incidence of complications related to PIVC in neonates hospitalized in the NICU was $63.15 \%$, with predominance of infiltration/extravasation, followed by phlebitis and 
obstruction. The risk factors for developing complications related to the use of catheters were: presence of infection and weight on the puncture day, type of infusion 'intermittent infusion associated with continuous infusion', EI concomitant with PIVC use, catheter use for infusion of basic plan, TPN, blood transfusion associated with other infusions and administration of other drugs. There was also an even greater risk of developing complications in the first 48 hours after puncture. The intermittent infusion is the most suitable type for catheter maintenance. The TPN administration is not recommended for PIVC. The exclusive use of the catheter for blood transfusion reduces the risk of complications.

\section{RESUMO}

Objetivo: Avaliar a incidência de complicações relacionadas ao uso do cateter intravenoso periférico em neonatos e identificar fatores de risco associados. Método: Coorte prospectiva, realizada em Unidade de Terapia Intensiva Neonatal. Os participantes foram os neonatos internados submetidos à punção intravenosa periférica, no período de fevereiro a junho de 2013. Resultados: A incidência de complicações foi de 63,15\%, sendo infiltração/extravasamento $(69,89 \%)$, flebite $(17,84 \%)$ e obstrução (12,27\%). Os fatores de risco foram: presença de infecção $(p=0,0192)$ e peso no dia da punção $(p=0,0093)$, tipo de infusão intermitente associada à contínua $(p<0,0001)$, intubação orotraqueal ( $p=0,0008)$, infusão de plano básico $(p=0,0027)$, nutrição parenteral total $(p=0,0002)$, hemotransfusão associada a outras infusões $(\mathrm{p}=0,0003)$ e outros medicamentos $(\mathrm{p}=0,0004)$. Maior risco de desenvolver complicação nas primeiras 48 horas pós-punção. Conclusão: Uma taxa elevada de complicações relacionadas ao uso do cateter intravenoso periférico e fatores de risco associados à infecção, peso, drogas e soluções infundidas e tipo de infusão.

\section{DESCRITORES}

Recém-Nascido; Cateterismo Periférico; Fatores de Risco; Enfermagem Neonatal.

\section{RESUMEN}

Objetivo: Evaluar la incidencia de complicaciones relacionadas con el uso del catéter intravenoso periférico en neonatos e identificar factores de riesgo asociados. Método: Cohorte prospectiva, realizada en Unidad de Cuidados Intensivos Neonatal. Los participantes fueron los neonatos hospitalizados sometidos a la punción intravenosa periférica, en el período de febrero a junio de 2013. Resultados: La incidencia de complicaciones fue del 63,15\%, siendo infiltración/fuga (69,89\%), flebitis (17,84\%) y obstrucción (12,27\%). Los factores de riesgo fueron: presencia de infección $(\mathrm{p}=0,0192)$ y peso el día de la punción $(\mathrm{p}=0,0093)$, tipo de infusión intermitente asociada con la continua $(\mathrm{p}<0,0001)$, intubación orotraqueal $(\mathrm{p}=0,0008)$, infusión de plano básico $(\mathrm{p}=0,0027)$, nutrición parenteral total $(p=0,0002)$, hemotransfusión asociada con otras infusiones $(p=0,0003)$ y otros fármacos $(p=0,0004)$. Mayor riesgo de desarrollar complicación las primeras 48 horas post punción. Conclusión: Un índice elevado de complicaciones relacionadas con el uso del catéter intravenoso periférico y factores de riesgo asociados con la infección, peso, drogas y soluciones infundidas y tipo de infusión.

\section{DESCRIPTORES}

Recién Nacido; Cateterismo Periférico; Factores de Riesgo; Enfermería Neonatal.

\section{REFERENCES}

1. Johann DA, Lazzari LSM, Pedrolo E, Mingorance P, Almeida TQR, Danski MTR. Peripherally inserted central catheter care in neonates: an integrative literature review. Rev Esc Enferm USP [Internet]. 2012 [cited 2015 May 14];46(6):1503-11. Available from: http://www.scielo. br/pdf/reeusp/v46n6/en_30.pdf

2. Pop RS. A pediatric peripheral intravenous infiltration assessment tool. J Infus Nurs. 2012;35(4):243-8.

3. Perez A, Feuz I, Brotschi B, Bernet V. Intermittent flushing improves cannula patency compared to continuous infusion for peripherally inserted venous catheters in newborns: results from a prospective observational study. J Perinat Med. 2012;40(3):311-4.

4. O'Grady NP, Alexander M, Burns LA, Dellinger P, Garland J, Heard SO, et al.; Healthcare Infection Control Practices Advisory Committee. Guidelines for the prevention of intravascular catheter-related infections [Internet]. Atlanta: CDC; 2011 [cited 2015 May 12]. Available from: http://www.cdc.gov/hicpac/pdf/guidelines/bsi-guidelines-2011.pdf

5. Pérez JM, Rodríguez LR, Villanueva SG, Llarena RMR. Utilización y mantenimiento de los cateteres venosos periféricos en la unidad de neonatología del Hospital Universitario Río Hortega, Valladolid. Rev Enferm CyL [Internet]. 2015 [citado 2015 ago. 04]; 7(1):1-11. Disponible en: http://www.revistaenfermeriacyl.com/index.php/revistaenfermeriacyl/article/view/143/121

6. Barbosa MTSR, Alves VH, Rodrigues DP, Branco MBLR, Souza RMP, Bonazzi VCAM. Indicadores de qualidade na assistência de terapia intravenosa em um hospital universitário: uma contribuição da enfermagem. J Res Fundam Care [Internet]. 2015 [citado 2015 ago. 18];7(2):2277-86. Disponível em: http://www.seer.unirio.br/index.php/cuidadofundamental/article/view/3551

7. Arnts IJ, Heijnen JA, Wilbers HT, van der Wilt GJ, Groenewoud JM, Liem KD. Effectiveness of heparin solution versus normal saline in maintaining patency of intravenous locks in neonates: a double blind randomized controlled study. J Adv Nurs. 2011;67(12):2677-85.

8. Hetzler R, Wilson M, Colina EK, Hollenback C. Securing pediatric peripheral i.v. catheters - - application of an evidence-based practice model. J Pediatr Nurs. 2011; 26(2):143-8.

9. Wu J, Mu D. Vascular catheter-related complications in newborns. J Paediatr Child Health. 2012;48(2):E91-5.

10. Lages CDR, Sousa JCO, Cunha KJB, Costa e Silva N, Santos TMMG. Fatores preditores para admissão do recém-nascido na unidade de terapia intensiva. Rev Rene [Internet]. 2014 [citado 2015 ago. 18];15(1):3-11. Disponível em: http://www.revistarene.ufc.br/revista/index. php/revista/article/viewFile/1395/pdf 
11. Restieaux M, Max A, Broadbent R, Jackson P, Barker D, Wheeler B. Neonatal extravasation injury: prevention and management in Australia and New Zealand-a survey of current practice. BMC Pediatr [Internet]. 2013 [cited 2015 Mar 30];13:34-8. Available from: http://www. ncbi.nlm.nih.gov/pmc/articles/PMC3599986/

12. Clark E, Giombra BK, Hingl J, Doellman D, Tofani B, Johnson N. Reducing risk of harm from extravasation. J Infus Nurs. 2013;36(1):37-45.

13. Infusion Nurses Society. Infusion nursing standards of practice. J Infus Nurs [Internet]. 2011 [cited 2015 Mar 30];34(1S). Available from: http://www.ins1.org/files/public/11_30_11_standards_of_practice_2011_cover_toc.pdf

14. Intravenous Nursing New Zealand Incorporated Society. Provisional infusion therapy standards of practice [Internet]. New Zealand; 2012 [cited 2015 Mar 30]. Available from: http://www.ivnnz.co.nz/files/file/7672/IVNNZ_Inc_Provisional_Infusion_Therapy_Standards_ of_Practice_March_2012.pdf

15. Gorski LA, Hallock D, Kuehn SC, Morris P, Russell JM, Skala LC. Recommendations for frequency of assessment of the short peripheral catheter site. J Infus Nurs. 2012; 35(5):290-2.

16. Hadaway L. Short peripheral intravenous catheters and infections. J Infus Nurs. 2012; 35(4):230-40.

17. Lanzillotti LS, Seta MH, Andrade CLT, Mendes Junior WV. Adverse events and other incidents in neonatal intensive care units. Ciênc Saúde Coletiva [Internet]. 2015 [citado 2015 ago. 18];20(3):937-46. Available from: http://www.scielo.br/pdf/csc/v20n3/1413-8123csc-20-03-00937.pdf

18. Cardemil PB, Durán CC. Factores de riesgo de infecciones deltracto sanguíneo associadas a alimentación parenteral en pacientes pediátricos. Nutr Hosp. 2011;26(6):1428-34. 